\title{
Bacillus patagoniensis sp. nov., a novel alkalitolerant bacterium from the rhizosphere of Atriplex lampa in Patagonia, Argentina
}

\author{
Correspondence \\ Nelda Olivera \\ olivera@cenpat.edu.ar
}

\author{
Nelda Olivera, ${ }^{1} \dagger$ Faustino Siñeriz ${ }^{1,2}$ and Javier D. Breccia ${ }^{1,3}$ \\ ${ }^{1}$ PROIMI Planta Piloto de Procesos Industriales Microbiológicos, Av. Belgrano y Pasaje \\ Caseros, 4000 San Miguel de Tucumán, Tucumán, Argentina \\ ${ }^{2}$ Cátedra de Microbiología Superior, Facultad de Bioquímica, Química y Farmacia, Universidad \\ Nacional de Tucumán, San Miguel de Tucumán, Argentina \\ ${ }^{3}$ Cátedra de Microbiología de Alimentos, Facultad de Ciencias Exactas y Naturales, Universidad \\ Nacional de La Pampa, Uruguay 151, 6300 Santa Rosa, La Pampa, Argentina
}

\begin{abstract}
A Gram-positive, rod-shaped, spore-forming bacterium (PAT $05^{\top}$ ) was isolated from the rhizosphere of the perennial shrub Atriplex lampa in north-eastern Patagonia, Argentina. Its overall biochemical and physiological characteristics indicated that this strain should be placed in the alkaliphilic Bacillus group. Strain PAT $05^{\top}$ grew at $\mathrm{pH} 7-10$ (optimum $\mathrm{pH}$ 8), but not at $\mathrm{pH}$ 6. Its DNA G $+\mathrm{C}$ content was $39 \cdot 7 \mathrm{~mol} \%$. Sequence analysis of the $16 \mathrm{~S}$ rRNA gene of PAT $05^{\top}$ revealed the closest match (99.6\% similarity) with Bacillus sp. DSM 8714. The highest level of DNA-DNA relatedness (88.6\%) was also found with this strain. On the basis of $16 \mathrm{~S}$ rRNA gene sequence similarity and phylogenetic analysis, $G+C$ content and DNA-DNA hybridization data, strain PAT $05^{\top}$ is related at the species level to Bacillus sp. DSM 8714, a member of a group referred as phenon $4 \mathrm{a}$ by Nielsen et al. [Nielsen, P., Fritze, D. \& Priest, F. G. (1995). Microbiology 141, 1745-1761], which still lacks taxonomic standing. These results support the proposal of strain PAT $05^{\top}\left(=\mathrm{DSM} 16117^{\top}=\right.$ ATCC BAA-965 $\left.5^{\top}\right)$ as the type strain of Bacillus patagoniensis sp. nov.
\end{abstract}

The classification of alkaliphilic Bacillus species has been subject to revisions that have involved their phylogenetic and phenotypic characteristics (Fritze et al., 1990; Nielsen et al., 1994, 1995). As a result of these studies, nine novel species were described, Bacillus agaradhaerens, Bacillus clarkii, Bacillus clausii, Bacillus gibsonii, Bacillus halmapalus, Bacillus halodurans, Bacillus horikoshii, Bacillus pseudalkaliphilus and Bacillus pseudofirmus, in addition to the previously known species Bacillus cohnii and Bacillus alcalophilus. Since then, the classification of novel alkalitolerant and alkaliphilic strains has led to the proposal of species such as Bacillus vedderi (Agnew et al., 1995), Bacillus haloalkaliphilus (Fritze, 1996), Bacillus horti (Yumoto et al., 1998), Bacillus arseniciselenatis and Bacillus selenitireducens

Published online ahead of print on 10 September 2004 as DOI 10.1099/ijs.0.63348-0.

tPresent address: Centro Nacional Patagónico, Blvd Brown s/n, 9120 Puerto Madryn, Chubut, Argentina.

The GenBank/EMBL/DDBJ accession number for the $16 \mathrm{~S}$ rRNA gene sequence of strain PAT $05^{\top}$ is AY258614.

An electron photomicrograph of a negatively stained cell of strain PAT $05^{\top}$ is available as supplementary material in IJSEM Online.
(Switzer Blum et al., 1998), Bacillus okuhidensis (Li et al., 2002) and Bacillus krulwichiae (Yumoto et al., 2003).

Naturally occurring alkaline environments harbour a wide range of alkaliphilic micro-organisms. Desert soils, such as the arid soils in north-eastern Patagonia (Argentina), are exposed to wind and water erosion, as well as salinization and alkalinization processes associated with non-irrigated lands. The physical processes that cause losses of fine material, organic matter and nutrients from the topsoil lead to the concentration of soil resources underneath remnant plant patches (Mazzarino et al., 1996). There is very limited knowledge about the microbial diversity of Patagonian arid soils, especially from vegetated soil microsites characterized by alkaline and saline conditions.

During the characterization of proteolytic micro-organisms from such soils, the strain PAT $05^{\mathrm{T}}$ was isolated from the rhizosphere of Atriplex lampa, a perennial shrub that is able to colonize alkaline and saline areas. PAT $05^{\mathrm{T}}$ is a producer of alkaline proteases that, considering their characteristics such as high optimum $\mathrm{pH}$, high stability and residual activity in the presence of denaturing and chelating agents, could be a promising system enzyme for a detergent formulation (Olivera et al., 2003). This study 
focuses on phenotypic, phylogenetic and DNA-DNA relatedness analyses performed in order to establish the taxonomic position of strain PAT $05^{\mathrm{T}}$.

Strain PAT $05^{\mathrm{T}}$ was originally isolated using an agar medium composed of $1 \%(\mathrm{w} / \mathrm{v})$ skimmed milk, $0 \cdot 1 \%(\mathrm{w} / \mathrm{v})$ yeast extract, $5 \%(\mathrm{w} / \mathrm{v}) \mathrm{NaCl}$ and $0 \cdot 1 \mathrm{M} \mathrm{Na}_{2} \mathrm{CO}_{3}$ (separately autoclaved) to provide $\mathrm{pH} 10$ (Olivera et al., 2003). For routine growth, isolate PAT $05^{\mathrm{T}}$ was cultured in $\mathrm{LB}$ medium supplemented with $5 \%(\mathrm{w} / \mathrm{v}) \mathrm{NaCl}$ and $0 \cdot 1 \mathrm{M} \mathrm{Na}_{2} \mathrm{CO}_{3}$.

Phenotypic tests were based on the methods described by Claus \& Berkeley (1986) with media adjusted to approximately pH 10 according to Fritze et al. (1990). The API 50 $\mathrm{CH}$ gallery (bioMérieux) was used for carbohydrate utilization tests according to the procedure described by Nielsen et al. (1995). Acid production from carbohydrates was determined by the method of Hugh \& Leifson (1953) using thymol blue instead of bromothymol blue at $\mathrm{pH} 10$ (Yumoto et al., 2003). Doubling times at $\mathrm{pH} 6,7,8,9$ and 10 were evaluated in LB broth with $5 \% \mathrm{NaCl}(\mathrm{w} / \mathrm{v})$; triplicate cultures were incubated at 200 r.p.m. and $25^{\circ} \mathrm{C}$ and quantified by optical density at $600 \mathrm{~nm}$. Tolerance to salt was investigated by using different $\mathrm{NaCl}$ concentrations in LB broth, $0 \cdot 1 \mathrm{M} \mathrm{Na}_{2} \mathrm{CO}_{3}$. The effect of temperature on growth was determined in the same medium with $5 \% \mathrm{NaCl}$ and $0 \cdot 1 \mathrm{M} \mathrm{Na}_{2} \mathrm{CO}_{3}$. Cellular morphology and size and endospores were examined by phase-contrast microscopy (Carl Zeiss Photomicroscope III). Flagellation was examined using transmission electron microscopy (JEOL CX 100) of negatively stained cells (Tesche \& Schmiady, 1985).

The 16S rRNA gene sequence (corresponding to positions 27-1492 in the Escherichia coli gene) was amplified by PCR as described by DeLong (1992), using a GeneAmp model 2700 thermal cycler (Applied Biosystems). Sequencing of both strands of PCR-amplified fragments was performed using the dideoxy chain-termination method by the commercial services of GATC Biotech AG. 16S rRNA gene sequence similarity searches against the NCBI database were carried out using BLAST (Altschul et al., 1990). Sequences showing a relevant degree of similarity were imported into the CLUSTAL W program (Thompson et al., 1994), aligned and corrected manually. The percentage of similarity was calculated in the BioEdit program version 5.0.9 (Hall, 1999). Phylogenetic analyses were performed using the branch and bound parsimony algorithm with PAUP program version $4.0 \mathrm{~b} 10$ (Swofford, 2001). Sites involving gaps were treated as missing characters. The results were evaluated with 1000-replication jackknife analysis and the length and the consistency (CI) and retention (RI) indices of the trees were calculated.

The DNA G+C content was determined by reversephase HPLC by the commercial services of the Deutsche Sammlung von Mikroorganismen und Zellkulturen (DSMZ). DNA-DNA hybridization analyses were also performed by the DSMZ. DNA was isolated using a French pressure cell
(Thermo Spectronic) and purified by chromatography on hydroxyapatite as described by Cashion et al. (1977). Hybridization was carried out as described by De Ley et al. (1970), with the modifications described by Huß et al. (1983) and Escara \& Hutton (1980), using a model 2600 spectrophotometer equipped with a model 2527-R thermoprogrammer and plotter (Gilford Instrument Laboratories). Renaturation rates were computed with the TRANSFER.BAS program (Jahnke, 1992).

The overall biochemical and physiological characteristics (see species description) indicate that strain PAT $05^{\mathrm{T}}$ should be placed in the alkaliphilic Bacillus group. It grew as creamy white-coloured colonies and the cells were rodshaped with peritrichous flagella (an electron photomicrograph is available as supplementary material in IJSEM Online). Subterminal oval endospores were observed in slightly swollen sporangia (Fig. 1). Strain PAT $05^{\mathrm{T}}$ did not grow under anaerobic conditions. Most of its phenotypic properties are shown in Table 1 and they are compared with those of related alkalitolerant Bacillus strains. PAT $05^{\mathrm{T}}$ grew at $\mathrm{pH} 7-10$, while growth was undetectable at $\mathrm{pH} 6$. Optimal growth (doubling time, $t_{\mathrm{d}} 86 \mathrm{~min}$ ) was obtained at $\mathrm{pH} \mathrm{8}$, although it was able to grow at $\mathrm{pH} 7\left(t_{\mathrm{d}} 99 \mathrm{~min}\right)$, $\mathrm{pH} 9\left(t_{\mathrm{d}} 88 \mathrm{~min}\right)$ and $\mathrm{pH} 10\left(t_{\mathrm{d}} 106 \mathrm{~min}\right)$. The range of temperature for growth was $5-40{ }^{\circ} \mathrm{C}$. These results indicate that strain PAT $05^{\mathrm{T}}$ is an alkalitolerant/moderately alkaliphilic micro-organism, and its capacity to grow at low temperatures and high salinity revealed that it is also psychrotolerant and halotolerant (Table 1).

The $\mathrm{G}+\mathrm{C}$ content of genomic DNA of strain PAT $05^{\mathrm{T}}$ was $39.7 \mathrm{~mol} \%$, a value comparable to those found in a group of alkaliphilic Bacillus strains referred as phenon 4 by Nielsen et al. (1995). Analysis of 1422 bases of the 16S rRNA gene of PAT $05^{\mathrm{T}}$ confirmed that the closest match $(99.6 \%$ similarity) was to the sequence from the alkaliphilic Bacillus strain DSM 8714, which belongs to phenon 4 group a (Nielsen et al., 1994, 1995), and which still lacks taxonomic standing. The next highest similarity $(98 \cdot 0 \%)$

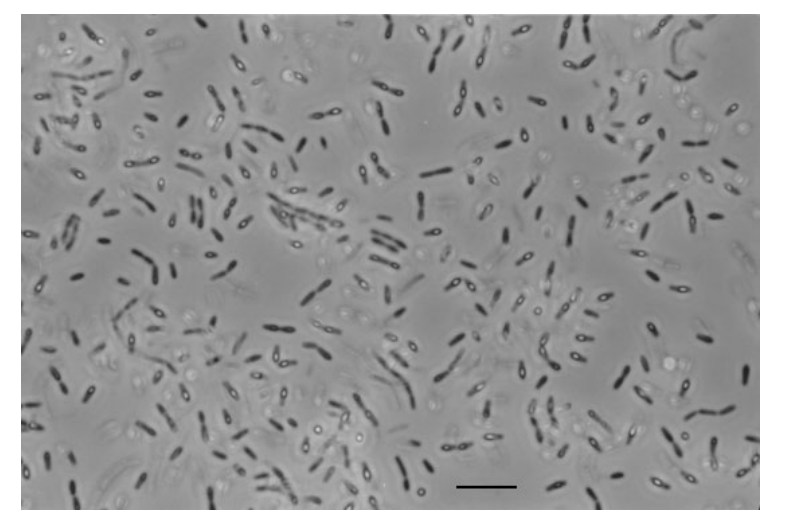

Fig. 1. Phase-contrast micrograph showing endospores of strain PAT $05^{\top}$. Bar, $10 \mu \mathrm{m}$. 
Table 1. Phenotypic characteristics of Bacillus patagoniensis sp. nov. and other alkalitolerant bacilli

Taxa: 1, B. patagoniensis sp. nov.; 2, Bacillus sp. phenon 4a; 3, Bacillus sp. phenon 4b; 4, B. clausii; 5, B. gibsonii; 6, B. halmapalus; 7, B. horikoshii. +, Positive; -, negative; V, variable; W, weakly positive. Data for reference taxa are from Nielsen et al. (1995).

\begin{tabular}{|lcccccccc|}
\hline Character & $\mathbf{1}$ & $\mathbf{2}$ & $\mathbf{3}$ & $\mathbf{4}$ & $\mathbf{5}$ & $\mathbf{6}$ & $\mathbf{7}$ \\
\hline Growth at: & & & & & & & \\
$10{ }^{\circ} \mathrm{C}$ & + & + & + & - & $\mathrm{V}$ & + & + \\
$40^{\circ} \mathrm{C}$ & $\mathrm{W}$ & - & + & + & - & + & + \\
$50{ }^{\circ} \mathrm{C}$ & - & - & - & + & - & - & - \\
Growth in NaCl: & & & & & & & \\
$5 \%$ & + & + & + & + & + & - & + \\
$10 \%$ & + & + & + & $\mathrm{V}$ & $\mathrm{V}$ & - & - \\
15\% & + & + & + & - & - & - & - \\
Hydrolysis of: & & & & & & & \\
Starch & + & + & + & + & - & + & + \\
Tween 20 & + & - & - & - & - & - & - \\
Tween 40 & + & - & - & - & $\mathrm{V}$ & - & $\mathrm{V}$ \\
Tween 60 & + & - & - & - & $\mathrm{V}$ & - & $\mathrm{V}$ \\
MUG & - & - & - & - & + & - & - \\
Nitrate reduction & - & - & - & + & $\mathrm{V}$ & - & - \\
Utilization of: & & & & & & & \\
L-Arabinose & - & - & $\mathrm{V}$ & + & + & - & - \\
D-Ribose & + & - & $\mathrm{V}$ & + & + & - & $\mathrm{V}$ \\
D-Xylose & - & - & $\mathrm{V}$ & + & $\mathrm{V}$ & $\mathrm{V}$ & $\mathrm{V}$ \\
D-Mannose & + & $\mathrm{V}$ & $\mathrm{V}$ & + & + & + & $\mathrm{V}$ \\
L-Rhamnose & + & - & - & + & $\mathrm{V}$ & - & - \\
Dulcitol & - & - & $\mathrm{V}$ & + & - & - & - \\
D-Sorbitol & + & - & - & + & - & - & - \\
Methyl $\alpha$-D-glucoside & - & $\mathrm{V}$ & $\mathrm{V}$ & + & - & - & $\mathrm{V}$ \\
N-Acetylglucosamine & + & $\mathrm{V}$ & $\mathrm{V}$ & + & - & + & + \\
Amygdalin & - & $\mathrm{V}$ & $\mathrm{V}$ & + & $\mathrm{V}$ & + & $\mathrm{V}$ \\
Salicin & + & $\mathrm{V}$ & $\mathrm{V}$ & + & + & $\mathrm{V}$ & - \\
D-Lactose & - & - & - & $\mathrm{V}$ & + & - & - \\
D-Melibiose & - & $\mathrm{V}$ & $\mathrm{V}$ & + & + & - & - \\
D-Melezitose & - & $\mathrm{V}$ & $\mathrm{V}$ & + & + & - & - \\
D-Raffinose & + & $\mathrm{V}$ & $\mathrm{V}$ & + & + & - & - \\
Starch & - & - & $\mathrm{V}$ & + & - & + & + \\
Glycogen & - & - & - & + & - & + & + \\
Xylitol & - & - & $\mathrm{V}$ & + & - & - & - \\
Gentiobiose & + & - & $\mathrm{V}$ & $\mathrm{V}$ & + & - & $\mathrm{V}$ \\
D-Turanose & + & - & $\mathrm{V}$ & + & + & + & $\mathrm{V}$ \\
D-Lyxose & & & & + & - & - & - \\
\hline
\end{tabular}

${ }^{\star} 4$-Methylumbelliferyl $\beta$-D-glucuronide.

was to Bacillus sp. WW3-SN6 (Ntougias \& Russell, 2000). Similarity values in the range $95 \cdot 3-89 \cdot 5 \%$ were obtained when comparing the $16 \mathrm{~S}$ rRNA gene sequence of PAT $05^{\mathrm{T}}$ to those of type strains of alkaliphilic Bacillus species described by Nielsen et al. (1995). The highest similarity values $(96 \cdot 2$ and $95 \cdot 3 \%)$ with strains characterized to the species level were to B. clausii SIN84 Enterogermina (Senesi et al.,

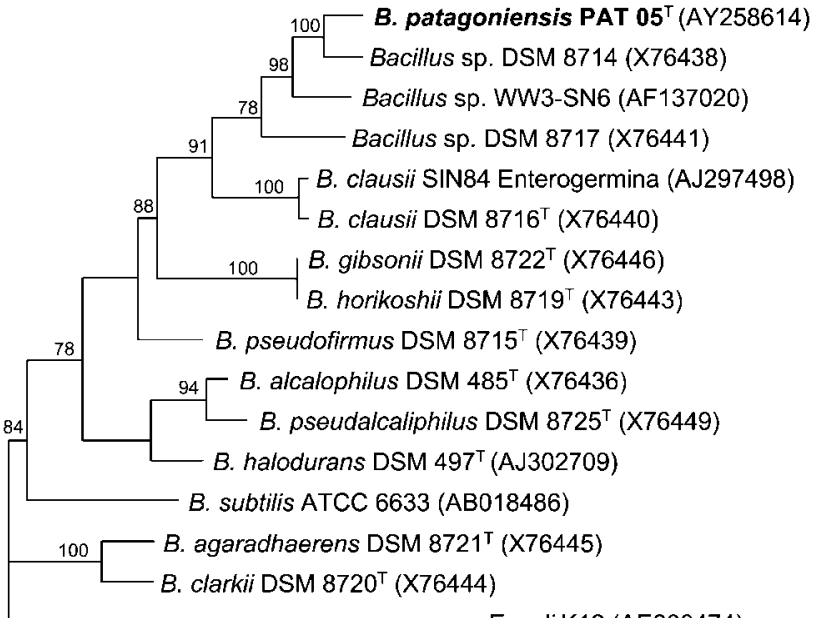

E. coli K12 (AE000474)

Fig. 2. Most-parsimonious phylogenetic tree of strain PAT $05^{\top}$ derived from $16 \mathrm{~S}$ rRNA gene sequence data. Numbers at internal nodes are jackknife support values (\%). The 16S rRNA gene sequence of $E$. coli was chosen arbitrarily as the outgroup sequence.

2001) and the type strain of B. clausii, DSM $8716^{\mathrm{T}}$, respectively. Levels of similarity between $16 \mathrm{~S}$ rRNA gene sequences below $97 \%$ suggest that the strains do not correspond to the same species (Stackebrandt \& Goebel, 1994).

To characterize strain PAT $05^{\mathrm{T}}$ further, a phylogenetic tree based on its 16S rRNA gene sequence was constructed (Fig. 2). From the total of $1422 \mathrm{bp}, 183$ were parsimony informative. A single most-parsimonious tree was obtained; its length was 750 steps and the CI and RI were respectively $0 \cdot 7120$ and $0 \cdot 6516$. The phylogenetic tree revealed that PAT $05^{\mathrm{T}}$ forms a distinct clade in the alkaliphilic Bacillus tree together with Bacillus spp. DSM 8714, WW3SN6 and DSM 8717. The taxonomic integrity of this clade was supported by the $78 \%$ jackknife value obtained. The cladogram also showed that this clade is the sister group of the clade containing B. clausii strains, with $91 \%$ recovery in jackknife analysis. These results confirmed that PAT $05^{\mathrm{T}}$ is closely related to taxa referred to as phenon 4 groups a and b, whose reference strains are Bacillus spp. DSM 8714 and DSM 8717, respectively (Nielsen et al., 1995). As was the case for PAT $05^{\mathrm{T}}$, soil was the source of isolation of group $4 \mathrm{a}$ strains, while group $4 \mathrm{~b}$ strains were isolated from animal manures.

The DNA-DNA hybridization results support the conclusion that strains PAT $05^{\mathrm{T}}$ and Bacillus sp. DSM 8714 are related at the species level, with $88.6 \%$ DNA-DNA relatedness (in $2 \times \mathrm{SSC}$ at $64^{\circ} \mathrm{C}$ ), while PAT $05^{\mathrm{T}}$ and Bacillus sp. DSM 8717 are not (20.5\% DNA-DNA relatedness). The recommendations of the ad hoc committee (Wayne et al., 1987) considered a threshold value of $70 \%$ DNA-DNA relatedness for definition of bacterial species. 
All these results confirmed that strain PAT $05^{\mathrm{T}}$ should be classified in a novel species together with strains belonging to phenon 4a (Nielsen et al., 1995). We propose the name Bacillus patagoniensis sp. nov., the type strain being PAT $05^{\mathrm{T}}$ $\left(=\right.$ DSM $16117^{\mathrm{T}}=$ ATCC BAA- $\left.965^{\mathrm{T}}\right)$.

\section{Description of Bacillus patagoniensis sp. nov.}

Bacillus patagoniensis (pa.ta.go'ni.en.sis. N.L. masc. adj. patagoniensis pertaining to Patagonia, in Argentina, where the type strain was isolated).

Cells are aerobic rods $(2 \cdot 4-3 \cdot 2 \times 0 \cdot 8-1 \cdot 1 \mu \mathrm{m})$ with peritrichous flagella and they occur singly, in pairs or in chains. Endospores are observed as subterminal oval spores. Colonies are cream-white. Gram, oxidase and catalase reactions are positive. Growth occurs at $\mathrm{pH} 7-10$, with an optimum at about $\mathrm{pH} 8$. There is growth between 5 and $40{ }^{\circ} \mathrm{C}$ and with $15 \% \mathrm{NaCl}$. Nitrate is not reduced to nitrite. Hydrolysis of casein, gelatin, starch and Tweens 20,40 and 60 is observed, but Tween 80 and 4-methylumbelliferyl $\beta$-D-glucuronide are not hydrolysed. Phenylalanine is not deaminated. Utilizes glycerol, D-ribose, D-glucose, Dfructose, D-mannose, L-rhamnose, D-mannitol, D-sorbitol, $\mathrm{N}$-acetylglucosamine, salicin, D-cellobiose, D-maltose, sucrose, D-trehalose, D-raffinose, gentiobiose, D-turanose and potassium 2-ketogluconate but not D-arabinose, Larabinose, D-xylose, D-galactose, L-sorbose, inositol, starch, xylitol, D-lyxose, D-arabitol or gluconate. Acid, but no gas, is produced from glycerol, D-glucose, D-mannitol, Dsorbitol, D-maltose, D-ribose, D-raffinose and D-cellobiose. The DNA G + C content of the type strain is $39 \cdot 7 \mathrm{~mol} \%$ as determined by HPLC.

The type strain is PAT $05^{\mathrm{T}}\left(=\right.$ DSM $16117^{\mathrm{T}}=$ ATCC BAA$965^{\mathrm{T}}$ ), isolated from the rhizosphere of the perennial shrub Atriplex lampa in north-eastern Patagonia, Argentina.

\section{Acknowledgements}

This work was supported by grants from the Agencia Nacional de Promoción Científica y Tecnológica (PICT 14-0486 BID 1201/OCAR), Consejo Nacional de Investigaciones Científicas y Técnicas (CONICET) Argentina, Agregaduría Científica de la Embajada de Italia en Argentina and Fundación Antorchas. The authors acknowledge equipment facilities from Chemical Oceanography and Molecular Biology Laboratories, Centro Nacional Patagónico (CENPATCONICET). Thanks are also due to Dr Mónica Bertiller for providing soil samples, Dr Néstor Basso and Dr Catalina Pastor for assistance with the phylogenetic and microscopic analyses, respectively.

\section{References}

Agnew, M. D., Koval, S. F. \& Jarrell, K. F. (1995). Isolation and characterization of novel alkaliphiles from bauxite-processing waste and description of Bacillus vedderi sp. nov., a new obligate alkaliphile. Syst Appl Microbiol 18, 221-230.

Altschul, S. F., Gish, W., Miller, M., Myers, E. W. \& Lipman, D. J. (1990). Basic local alignment search tool. J Mol Biol 215, 403-410.
Cashion, P., Holder-Franklin, M. A., McCully, J. \& Franklin, M. (1977). A rapid method for the base ratio determination of bacterial DNA. Anal Biochem 81, 461-466.

Claus, D. \& Berkeley, R. C. W. (1986). Genus Bacillus Cohn 1872, $174^{\mathrm{AL}}$. In Bergey's Manual of Systematic Bacteriology, vol. 2, pp. 1105-1139. Edited by P. H. A. Sneath, N. S. Mair, M. E. Sharpe \& J. G. Holt. Baltimore: Williams \& Wilkins.

De Ley, J., Cattoir, H. \& Reynaerts, A. (1970). The quantitative measurement of DNA hybridization from renaturation rates. Eur J Biochem 12, 133-142.

DeLong, E. F. (1992). Archaea in coastal marine environments. Proc Natl Acad Sci U S A 89, 5685-5689.

Escara, J. F. \& Hutton, J. R. (1980). Thermal stability and renaturation of DNA in dimethyl sulfoxide solutions: acceleration of the renaturation rate. Biopolymers 19, 1315-1327.

Fritze, D. (1996). Bacillus haloalkaliphilus sp. nov. Int J Syst Bacteriol 46, 98-101.

Fritze, D., Flossdorf, J. \& Claus, D. (1990). Taxonomy of alkaliphilic Bacillus strains. Int J Syst Bacteriol 40, 92-97.

Hall, T. A. (1999). BioEdit: a user-friendly biological sequence alignment editor and analysis program for Windows 95/98/NT. Nucleic Acids Symp Ser 41, 95-98.

Hugh, R. \& Leifson, E. (1953). The taxonomic significance of fermentative versus oxidative metabolism of carbohydrates by various Gram-negative bacteria. J Bacteriol 66, 24-26.

Huß, V. A. R., Festl, H. \& Schleifer, K. H. (1983). Studies on the spectrophotometric determination of DNA hybridization from renaturation rates. Syst Appl Microbiol 4, 184-192.

Jahnke, K. D. (1992). Basic computer program for evaluation of spectroscopic DNA renaturation data from GILFORD System 2600 spectrometer on a PC/XT/AT type personal computer. J Microbiol Methods 15, 61-73.

Li, Z., Kawamura, Y., Shida, O., Yamagata, S., Deguchi, T. \& Ezaki, T. (2002). Bacillus okuhidensis sp. nov., isolated from the Okuhida spa area of Japan. Int J Syst Evol Microbiol 52, 1205-1209.

Mazzarino, M. J., Bertiller, M. B., Sain, C., Laos, F. \& Coronato, F. (1996). Spatial patterns of nitrogen availability, mineralization, and immobilization in northern Patagonia, Argentina. Arid Soil Res Rehabil 10, 295-309.

Nielsen, P., Rainey, F. A., Outtrup, H., Priest, F. G. \& Fritze, D. (1994). Comparative $16 \mathrm{~S}$ rDNA sequence analysis of some alkaliphilic bacilli and the establishment of a sixth rRNA group within the genus Bacillus. FEMS Microbiol Lett 117, 61-66.

Nielsen, P., Fritze, D. \& Priest, F. G. (1995). Phenetic diversity of alkaliphilic Bacillus strains: proposal for nine new species. Microbiology 141, 1745-1761.

Ntougias, S. \& Russell, N. J. (2000). Bacillus sp. WW3-SN6, a novel facultatively alkaliphilic bacterium isolated from the washwaters of edible olives. Extremophiles 4, 201-208.

Olivera, N., Sequeiros, C., Marguet, E. R. \& Breccia, J. D. (2003). Extracellular proteolytic activity characterization of the alkaliphilic Bacillus sp. PAT 05 isolated from Patagonia arid soils, Argentina. In SINAFERM, pp. 1-7, article 148. Edited by W. Schmidell Netto. Florianópolis, Brazil: Universidade Federal de Santa Catarina Press.

Senesi, S., Celandroni, F., Tavanti, A. \& Ghelardi, E. (2001). Molecular characterization and identification of Bacillus clausii strains marketed for use in oral bacteriotherapy. Appl Environ Microbiol 67, 834-839.

Stackebrandt, E. \& Goebel, B. M. (1994). Taxonomic note: a place for DNA-DNA reassociation and $16 \mathrm{~S}$ rRNA sequence analysis in the present species definition in bacteriology. Int J Syst Bacteriol 44, 846-849. 
Switzer Blum, J., Burns Bindi, A., Buzzelli, J., Stolz, J. F. \& Oremland, R. S. (1998). Bacillus arsenicoselenatis, sp. nov., and Bacillus selenitireducens, sp. nov.: two haloalkaliphiles from Mono Lake, California that respire oxyanions of selenium and arsenic. Arch Microbiol 171, 19-30.

Swofford, D. L. (2001). PAUP: Phylogenetic analysis using parsimony, Version 4.0b10. Distributed by the Illinois Natural History Survey, Champaign, IL, USA.

Tesche, B. \& Schmiady, H. (1985). Comparative electron microscopic studies of single biomolecules negatively stained and freezedried metal-shadowed. Ultramicroscopy 16, 423-435.

Thompson, J. D., Higgins, D. G. \& Gibson, T. J. (1994). CLUSTAL W: improving the sensitivity of progressive multiple sequence alignment through sequence weighting, position-specific gap penalties and weight matrix choice. Nucleic Acids Res 22, 4673-4680.

Wayne, L. G., Brenner, D. J., Colwell, R. R. \& 9 other authors (1987). International Committee on Systematic Bacteriology. Report of the ad hoc committee on reconciliation of approaches to bacterial systematics. Int J Syst Bacteriol 37, 463-464.

Yumoto, I., Yamazaki, K., Sawabe, T., Nakano, K., Kawasaki, K., Ezura, Y. \& Shinano, H. (1998). Bacillus horti sp. nov., a new Gramnegative alkaliphilic bacillus. Int J Syst Bacteriol 48, 565-571.

Yumoto, I., Yamaga, S., Sogabe, Y., Nodasaka, Y., Matsuyama, H., Nakajima, K. \& Suemori, A. (2003). Bacillus krulwichiae sp. nov., a halotolerant obligate alkaliphile that utilizes benzoate and $\mathrm{m}$ hydroxybenzoate. Int J Syst Evol Microbiol 53, 1531-1536. 